\title{
Protonterapi i Norge?
}

\author{
Protonterapi til behandling av kreft brukes ikke i Norge. Metoden har potensielle fordeler \\ sammenliknet med tradisjonell strålebehandling, men det mangler tilfredsstillende \\ kliniske bevis. Noen mener det er uetisk å gjøre randomiserte kliniske studier med denne \\ behandlingen. God økonomi, gode kreftregistre og et ønske om å være et foregangsland \\ $i$ helsesektoren tilsier at Norge bør ta del i videreutviklingen av metoden.
}

\section{Einar Waldeland}

einar.waldeland@oslo-universitetssykehus.no Avdeling for medisinsk fysikk

Oslo universitetssykehus, Radiumhospitalet

La meg hoppe inn i en pågående debatt som dreier seg om kjernepartikler med en hastighet nær lysets. Målet er destruering av uønskede fremmedlegemer. Saken er krigen mot kreft og våpenet er protoner - tunge, ladede kjernepartikler som styres mot kreftceller for å drepe dem.

De siste årene har det kommet krav fra vitenskapsmenn og pasienter om at vi i Norge må starte med protonterapi (1). Det har vært nedsatt en nasjonal fagkomité for å vurdere protonterapi som behandlingform $(2,3), \mathrm{og}$ flere politikere har engasjert seg i saken (4, 5). $\mathrm{Og}$ - for å foregripe begivenheten hovedgrunnen til at vi ikke har protonterapi her i landet er prisen. En investering i et protonanlegg vil være i størrelsesorden en milliard kroner, altså 1/80 lyntogbane fra Oslo til Trondheim eller en kvart opera.

\section{Konvensjonell stråleterapi}

Hvert år făr om lag 25000 personer beskjed om at de har kreft. Dette tallet er forventet å øke med $30 \%$ frem mot år 2020, ifølge Kreftregisteret $(6,7)$. Rundt halvparten av disse vil få stråleterapi som et ledd i behandlingen, enten som eneste behandling eller i kombinasjon med kirurgi og/eller cellegift. Den tradisjonelle stråleterapien er godt utbygd i Norge, og maskinkapasiteten er tilstrekkelig for dagens bruk. Det er likevel et stort behov for jevnlige investeringer, både til fornying av utstyret og til oppjustering av kapasiteten på grunn av økt kreftforekomst $\mathrm{i}$ årene som kommer. Etter en oppgradering av stråleterapikapasiteten i begynnelsen av dette tiåret har man nå i flere år vært underlagt strenge innsparingskrav fra sykehus som går med gigantiske underskudd. I likhet med mye medisinsk-teknisk utstyr i sykehussektoren øker gjennomsnittsalderen på stråleterapiutstyret dramatisk.
Innen den tradisjonelle (eller konvensjonelle) stråleterapien benytter man seg av høyenergetisk røntgenstråling for å inaktivere eller drepe kreftceller. Strålingen rettes så presist som mulig inn mot området der kreftsvulsten eller risikoområdet befinner seg. I dag har man flere sofistikerte metoder for å strålebehandle pasienter, og de forbedres stadig. Ulempen ved strålebehandling (og også ved annen kreftbehandling, som kirurgi og cellegift) er at det praktisk talt er umulig å fjerne eller skade kun kreftcellene. Det er fordi det kan være vanskelig å bestemme hvor svulsten starter og slutter, fordi svulsten ligger dypt eller fordi man behandler risikoområder der det med en viss sannsynlighet befinner seg kreftceller, men der det også er godt mulig at mesteparten av cellene som behandles er friske.

\section{Å kurere kreft med protoner}

Protoner er relativt tunge partikler som ikke spres så mye på veien til kreftsvulsten.

Selve prosessen, der bevegelsesenergien til de hurtiggående partiklene går med til å inaktivere celler, skjer på en effektiv måte i kreftsvulsten - det er minimalt med stråling som kommer gjennom til det friske vevet på baksiden. Sammenliknet med konvensjonell stråleterapi kan strålingsdosen til det friske vevet omkring være betydelig lavere. Uønsket stråling til normalt vev kan gi akutte bivirkninger, men muligheten for utvikling av stråleindusert kreft er også en bekymring, særlig når barn behandles. Slike ettervirkninger kan gjerne ikke observeres før flere tiår etter behandlingen.

Da dosen utenfor svulsten blir mindre ved protonbehandling enn ved tradisjonell strålebehandling, kan man i noen tilfeller øke strålingsdosen til kreftsvulsten uten at det gir større bivirkninger - og da også øke sannsynligheten for helbredelse. Siden behandlingsmetodens virkemåte likner konvensjonell stråleterapi, men med muligheter for å generere bedre behandlingsplaner, kan det diskuteres om bruk av protoner i prinsippet er en ny behandlingsform eller om det er en utvikling eller forbedring av den tradisjonelle stråleterapien.

Protonbehandling har foregått i flere tiår. Stort sett har dette skjedd ved forskningsanlegg der man også har behandlet pasienter. Det siste tiåret har det vært en utvikling mot at anleggene blir skreddersydd for pasientbehandling. På verdensbasis er det nå oppført en del protonanlegg, og i Sverige er det ett under bygging. Teknologien og metodene for protonbehandling er under utvikling og det mangler i noen grad standardisering, uten at dette faktum endrer noe ved de fordelaktige sidene protonterapi kan ha.

I 2006 la en gruppe norske fagfolk frem en rapport om de kliniske resultatene av protonbehandling $(2,3)$. De oppsummerte at de kliniske bevisene var for mangelfulle til at man kunne trekke konklusjonen at protonbehandling var tradisjonell behandling overlegen hos aktuelle pasientgrupper og at metoden foreløpig måtte anses å være utprøvende behandling. Videre konstaterte de at for at den skulle kunne anerkjennes som standardbehandling for visse diagnoser, måtte det gjennomføres flere randomiserte kliniske studier.

\section{Protonterapi og randomiserte kliniske studier}

For at et legemiddel eller en behandlingsform skal kunne tas i bruk, er det strenge og anerkjente regler for hvilke tester som skal gjennomføres. Det vil alltid være et krav om randomiserte kliniske studier. Når det dreier seg om protonterapi, har det vært stilt spørsmål ved om slike studier er nødvendige, mulige eller etisk forsvarlige $(8,9)$. Hvis protonterapi kun er en forbedring av den tradisjonelle stråleterapien, er det da nødvendig å gjøre slike studier? Da forskjeller mellom protonterapi og tradisjonell strålebehandling kan vise seg mer enn 20 år etter at pasientene er behandlet og det er vanskelig å vite om pasientgrunnlaget vil bli stort nok til å trekke konklusjoner før lenge etter dette, vil det være mulig å gjennomføre disse studiene? Vil man få et tilstrekkelig antall pasienter som sier seg 


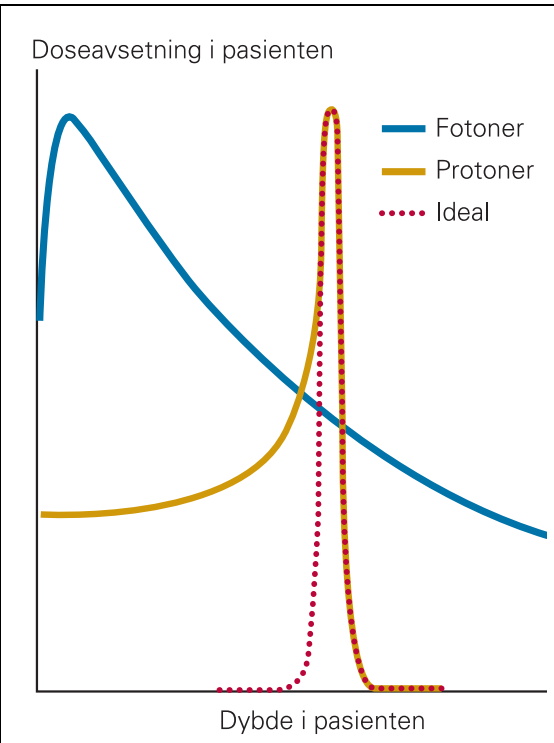

Doseavsetningen innover i en pasient ved tradisjonell strålebehandling (fotoner) og protonterapi. Mens doseavsetningen fra fotonene er størst ved grunne dyp, har protonene en karakteristisk avlevering av strålingsdosen mot slutten av deres rekkevidde. Dette gjør at protoner har bedre tilpasning av doseavsetningen enn fotoner når svulsten ligger dypt

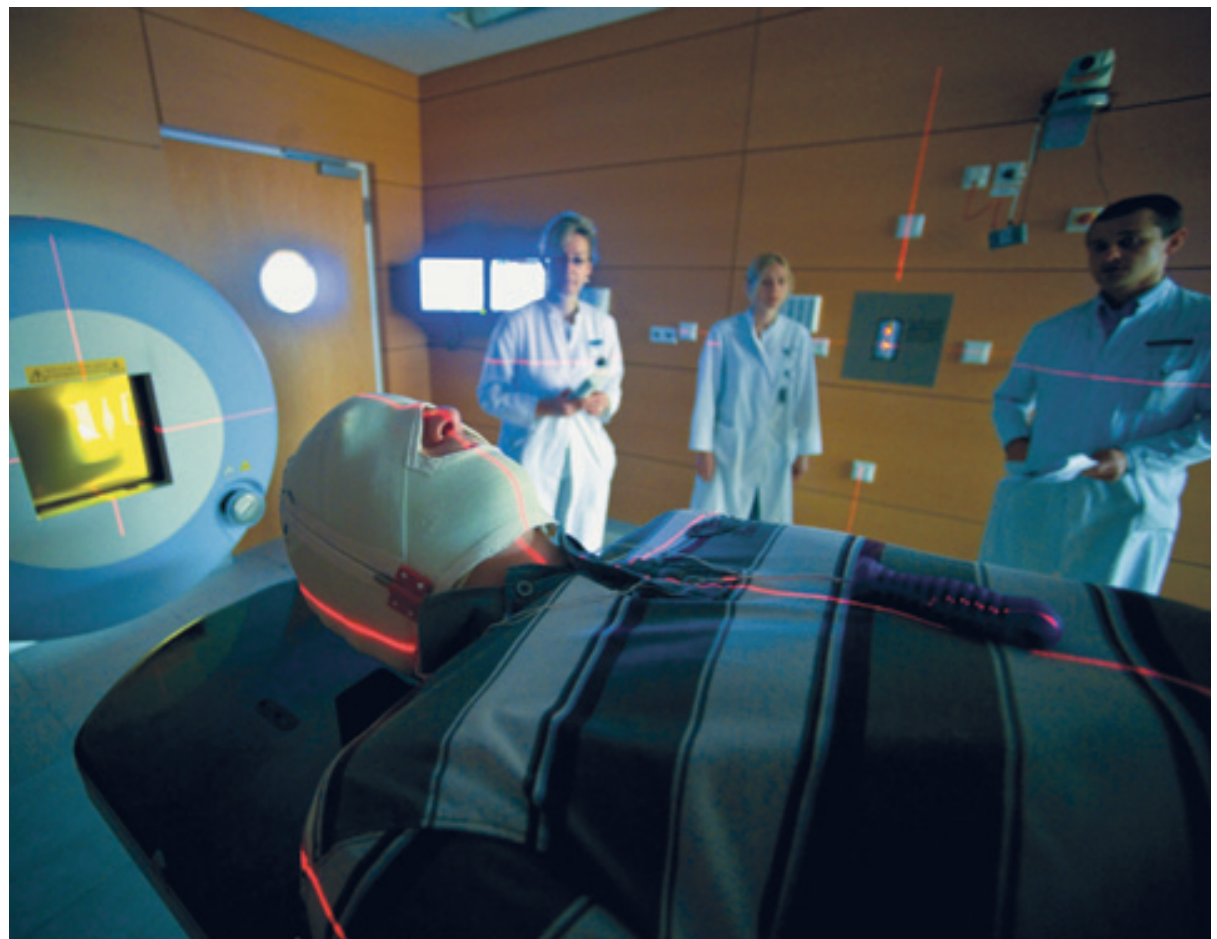

I Sverige er det bestemt at det skal bygges et senter for protonbehandling i Uppsala. Her en pasient som får strålebehandling med protoner ved Heidelberger lonenstrahl-Therapiezentrum i Tyskland. Foto Universitätsklinikum Heidelberg

bivirkninger. Går det an å snu på flisa og si at «bevisbyrden» ligger på den konvensjonelle stråleterapien - det må bevises at den er bedre enn protonterapi for at den fortsatt skal være standard (9)?

\section{Det økonomiske argumentet}

Protonterapi er en stor investering. Det kreves vilje til handling og handlekraft for å initiere investeringen. Så lenge private aktører ikke er deltakere i stråleterapi mot kreft, vil det måtte argumenteres overfor politikerne. Prisen per behandling (når det tas høyde for investering og drift) kan være 1,7 ganger høyere enn prisen for ordinær strålebehandling (12). Dette er likevel udramatisk, da prisen på stråleterapi utgjør $5-10 \%$ av kostnadene ved all kreftbehandling (13). Likevel har en slik startinvestering satt en effektiv stopper for prosessen.

I Norge er det tradisjon for at staten tar ansvaret for all kreftbehandling. På den måten sikrer man lik og forhåpentligvis god behandling for alle. Skepsisen mot å slippe private aktører inn i sykehusene er stor. Dette fører til at alternativer som ikke innebærer statlig investering, ikke blir vurdert. Så kan man spørre seg hvordan våre naboland Danmark og Sverige, med liknende statlige finansieringsmodeller, klarer å få til større satsing på området stråleterapi innen kreftforskningen enn det man i Norge kan drømme om.

\section{Prioritering}

Hvordan kan en storsatsing på protonterapi rettferdiggjøres $-\mathrm{i}$ forhold til alt det andre man kan satse på? I første omgang må man se bort fra andre sektorer enn kreftsektoren i sammenlikningen. I Norge velger vi å behandle mennesker for å bedre deres livskvalitet, selv om man kunne investert de samme midlene annerledes for å redde flere liv - for eksempel kunne vi brukt pengene på nødhjelp i utviklingsland. Siden dette er et faktum, bør man heller se på hvordan de pengene som går til kreftbehandling brukes i Norge. At protonterapi kan være et konkurransedyktig og kanskje endatil billig alternativ for kreftbehandling, må ikke undervurderes. Kan man enes om at et bedre behandlingsalternativ for 1500 pasienter i året (14) bør innføres, selv med en investeringsramme på rundt en milliard kroner, om bare de kliniske bevisene er der? Da vil det være vanskelig å komme utenom at vi i Norge bør bidra til forskning frem mot slike kliniske bevis. Vi kan ikke innta en passiv holdning og samtidig kreve flere bevis.

En investering i protonterapi i Norge vil ikke bety å ta denne terapien i bruk som en akseptert og anerkjent behandlingsmodalitet i kreftbehandlingen, det innebærer å bygge opp et forskningsmiljø rundt pasientbehandlingen for å være med $i$ videreutviklingen av metoden. Det er forholdsvis bred enighet om at de kliniske bevisene for protonterapi er mangelfulle og at dette er en utprøvende behandling som virker lovende. Og selv om det kan være innvendinger mot randomiserte kliniske studier, er det mulig å designe gode studier som kan benyttes. Dette kan være prospekgjennom stråleterapiens historie at lavere doser til friskt vev gir færre alvorlige 
tive og retroprospektive ikke-randomiserte studier, men også randomiserte studier der protonterapi kan befinne seg i begge armene eller sammenliknes med andre behandlingsformer, for eksempel kirurgi (15).

\section{Bremsede prosesser}

Det er blitt hevdet at det har vært tilsvarende motstand nasjonalt og internasjonalt ved innføringen av andre teknologiske nyvinninger i kreftbehandlingen, som kobolt-60-behandlingsapparat, behandlingssimulatorer, høyenergetiske lineærakseleratorer og CT (9). Nyere avbildningsmetoder som MR og PET har møtt den samme motstanden nasjonalt. Det at vi har hatt liknende bremsede prosesser tidligere, er ikke noe godt argument for ukritisk innføring av protonterapi. Men vi bør kanskje være mer ydmyke og åpne for at teknologiske nyvinninger driver medisinen fremover - det gjelder både de som viser seg å være vellykket og de som viser seg å være feilsteg. Vi må ta noen sjanser ved å investere i utstyr som ikke allerede er fullstendig klinisk utprøvd, men som har en sannsynlig suksess! Slik vokser vi som intellektuell nasjon og bidrar til det globale fellesskapet. Til sjuvende og sist gir vi bedre behandling til mange - selv om resultatene ikke skulle bli udelt positive.

\section{Moralsk forpliktelse?}

De vanligste argumentene som brukes for norsk investering og implementering av protonterapi er at det er en bedre behandling enn dagens og at vi i Norge har et nasjonalt og globalt sosialt ansvar for å delta i utviklingen av nye behandlingsmodaliteter.

Ved å si at protonterapi er bedre enn andre alternativer, forutsettes det at lavere strålingseksponering til normalvev vil være bedre for pasienten. Normalt vil det hevdes at dette bør måles i bivirkninger eller eventuelt stråleindusert sekundærkreft, men slike variabler kan være vanskelige å kvantifisere. Argumentet bunner ut i antakelsen om at lavest mulig strålingsdose i områdene som ikke skal bestråles, er det beste for pasienten. Det andre argumentet, som sier at vi i Norge har en forpliktelse, noen hevder endatil en moralsk forpliktelse (14), til å innføre protonterapi, tar utgangspunkt $i$ at selv om det ikke er en fullstendig utprøvd og bevist effektiv behandlingsmetode, har vi et ansvar for å delta i dette arbeidet.

Det begrunnes med den nasjonalegoistiske argumentasjonsrekken:

- Norge er forpliktet å gi best mulig kreftbehandling til sine innbyggere

- Protonterapi gir lavere stråling til normalvevet enn annen behandling

- Det er veldokumentert at lavere stråling til normalvevet gir færre alvorlige bivirkninger
Konklusjon: Norge er forpliktet til å investere i protonterapi!

Og så har vi det globalsosialistiske motivet: - Kreft er en global helseutfordring for industri- og utviklingsland, og utfordringen krever massiv satsing på forskning og utvikling av nye behandlingsmodaliteter

- Kun industriland har ressursene som må til for å bidra til denne forskningen og utviklingen

- Norge er et industriland

Konklusjon: Norge må investere i forskning og utvikling i kreftsektoren! Investering i protonterapi er en god mulighet til å gjøre dette!

Problemene med disse argumentene er at de ikke utelukkende er anvendbare på protonterapi. Fra et utilitaristisk synspunkt vil begge argumentasjonsrekkene være gyldige, nettopp fordi resultatet er økt velvære for et stort antall pasienter. Likevel må pengene som brukes til dette formålet ikke gå på bekostning av penger som kunne ført til enda større økning av velværet på andre måter - og det forutsettes da at protonterapi erstatter «dårligere» kreftbehandling. En innvending mot en utilitaristisk begrunnelse er at den ikke begrenser det moralske ansvaret til anskaffelse av protonterapi. Vi får et ansvar for å investere penger i forskning som kan lede til bedre og mer kostnadseffektive behandlingsmetoder - og det kreves høy kunnskap og kompetanse (om det er mulig) for å prioritere hvordan midlene skal brukes for å oppnå størst mulig velferd for flest mulig.

Ønsker man å begrunne de moralske aspektene ut fra deontologisk etikk, eller pliktetikk, må argumentasjonen bygge på at en autoritet hevder at vi skal gi den beste behandling til innbyggerne eller at vi skal dele penger og kompetanse med dem som ikke har dette (utviklingsland). Dette er også problematisk, da vi heller ikke her kan anvende etikken direkte på protonterapi, men kun på protonterapi som en del av en større sammenheng. Man vil måtte veie satsing på utvikling av protonterapi mot bistandsbudsjettet eller mot andre investeringer i helsesektoren - og til sjuende og sist dreier det seg om prioriteringer i de offentlige budsjettene - der man ikke uten videre kan hevde objektive sannheter.

Vi kan dermed ikke si at vi i Norge har en velbegrunnet moralsk forpliktelse til å gjøre en slik investering, som med overveiende sannsynlighet vil gagne både norske og utenlandske pasienter. Det betyr ikke at protonterapi bør skrinlegges her i landet! Med våre økonomiske muligheter, våre gode kreftregistre og vårt ønske om å være foregangsland i helsesektoren bør det være en naturlig følge at det satses på protonterapi. Ved å investere i protonterapi tar vi et globalt ansvar.
Oppgitte interessekonflikter: Ingen

Jeg takker Dag Rune Olsen for interessante innspill og Maren Rognaldsen for konstruktive samtaler om manuskriptet.

\section{Litteratur}

1. Tidemann G. Ber om 720 millioner til ny kreftbehandling, UNIFORUM 3.2.2005. www.uniforum. uio.no/nyheter/2005/02/ber-om-720-millionertil-ny-kreftbehandling.html (3.2.2010).

2. Olsen DR, Bruland OS, Frykholm $\mathrm{G}$ et al. Proton therapy - a systematic review of clinical effectiveness. Radiother Oncol 2007; 83: 123-32.

3. Kunnskapssenteret. Protonterapi. Rapport fra Kunnskapssenteret nr. 11-2006. www. kunnskapssenteret.no/Publikasjoner/757.cms (2.3.2010).

4. Vogt Y. Kreftseier: protonterapi skal utredes. Apollon 31.3.2009. www.apollon.uio.no/vis/art/2009 1/ artikler/protonterapi utredning (3.2.2010).

5. Tidemann G. Protonterapi: Alvheim og Hagen vil ta opp saken. UNIFORUM 28.4.2005. www.uniforum. uio.no/nyheter/2005/04/protonterapi-alvheim-og hagen-vil-ta-opp-saken.html (3.2.2010).

6. Olsen DR. Kreft, en global utfordring. Dagsavisen 17.8.2009. www.dagsavisen.no/meninger/ article432772.ece (3.2.2010)

7. Cancer in Norway 2005. Predictions of cancer incidence by Health Region 2010-2020. Oslo: Kreftregisteret, 2005.

8. Glatstein E, Glick J, Kaiser L et al. Should randomized clinical trials be required for proton radiotherapy? An alternative view. J Clin Oncol 2008; 26 2438-9.

9. Goitein M, Cox JD. Should randomized clinical trials be required for proton radiotherapy? J Clin Oncol 2008; 26: 175-6.

10. Hellman S, Hellman DS. Of mice but not men problems of the randomized clinical-trial. N Engl J Med 1991; 324: 1585-9.

11. Hofmann B. Fallacies in the arguments for new technology: the case of proton therapy. J Med Ethics 2009: 35: 684-7.

12. Goitein $M$, Jermann M. The relative costs of proton and $X$-ray radiation therapy. Clin Oncol 2003; 15 S37-50.

13. Olsen DR, Smeland S. Protonterapi - men hva så? Dagsavisen 4.2.2008. www.dagsavisen.no/ meninger/article333486.ece (3.2.2010).

14. Spilde I. Fortsatt kreftsinke. forskning.no 18.8.2009. www.forskning.no/artikler/2009/august/ 226739 (3.2.2010)

15. Goitein M. Trials and tribulations in charged particle radiotherapy. Radiother Oncol 2009; doi: 10.1016/j.radonc.2009.06.012.

Manuskriptet ble mottatt 18.1. 2010 og godkjent 11.2. 2010. Medisinsk redaktør Siri Lunde. 